\title{
Bicentric Evaluation of a Teaching and Treatment Programme for Type 1 (Insulin-Dependent) Diabetic Patients: Improvement of Metabolic Control and other Measures of Diabetes Care for up to 22 Months
}

\author{
I. Mühlhauser ${ }^{1}$, V.Jörgens ${ }^{1}$, M.Berger ${ }^{1}$, W.Graninger ${ }^{3}$, W.Gürtler ${ }^{1}$, L.Hornke ${ }^{2}$, A. Kunz ${ }^{3}$, G.Schernthaner ${ }^{3}$, \\ V. Scholz ${ }^{1}$ and H. E. Voss ${ }^{1}$
}

'Department of Medicine E and 'Department of Education, University of Düsseldorf, FRG, and

${ }^{3}$ Second Medical Department, University of Vienna, Austria

\begin{abstract}
Summary: In two hospitals an identical diabetes teaching and treatment programme (in-patient, Monday to Friday, group teaching) was set up. Seventy-eight consecutive, conventionally treated Type 1 diabetic patients (duration of diabetes $10 \pm$ 6 years), referred during a certain period, were reinvestigated after 1 year, and again (for assessment of metabolic control only) 22 months after the teaching and treatment programme. Initially, mean glycosylated haemoglobin was $2.6 \%$, after one year $1.0 \%$, and after 22 months $1.5 \%$ above the upper limit of the normal range $(p<0.001)$. Hospital admissions were reduced from a mean of 10 to a median of 1 day per patient per year $(p<0.001)$. The long-term quality of diabetes care achieved by the diabetes teaching and treatment programme was unrelated to intelligence quotient, diabetes duration, or diabetes-related knowledge. Patients with normal levels of
\end{abstract}

glycosylated haemoglobin on follow-up ( $33 \%$ of all patients) had particularly good compliance rates, and significantly lower initial values of glycosylated haemoglobin than patients with glycosylated haemoglobin levels $\geqslant 10 \%$. The data indicate that the diabetes teaching and treatment programme resulted in a substantial long-term improvement of metabolic control and a striking reduction of hospital admissions. The study substantiates the feasibility of applying this teaching and treatment programme on a large scale to other hospitals, so as to improve the quality of diabetes care and decrease health care costs.

Key words: Diabetes education, Type 1 diabetes, severe hypoglycaemia, diabetes care.
Continuous (near-) normalization of glycaemia has lately regained general acceptance as the main goal for long-term treatment of young diabetic patients. Patients' diabetes-related knowledge and motivation to adhere to a cumbersome therapeutic regimen appear to be crucial for long-term success. However, education of the patients has been neglected during recent decades, when teaching has been delivered mainly on an unstructured basis without any systematic attempt to evaluate its long-term effectiveness [1,2]. A few studies have shown that structured diabetes teaching programmes lead to a reduction of admissions to hospital [3, 4], ketoacidosis $[3,5]$ and diabetes-related lower limb amputations $[5,6]$. On the other hand, reports concerning the long-term effects of diabetes teaching and treatment programmes on metabolic control have been scarce, and their results disappointing [7, 8].

The primary aim of this study was to investigate the influence of a structured diabetes teaching and treatment programme, both on metabolic control and other measures of diabetes care, and on possible causes of differences between patient groups with regard to the efficiency of the intervention. To this end, we have eval- uated a 1-week in-patient diabetes teaching and treatment programme in two university hospitals over follow-up periods of 1 and 2 years in unselected, conventionally treated Type 1 (insulin dependent) diabetic patients.

\section{Patients and Methods}

\section{Diabetes Teaching and Treatment Programme}

The study was carried out at the Departments of Medicine of the University Hospitals of Vienna and Düsseldorf. Each has a long tradition as a centre for the care of diabetic patients, with a special diabetes ward and an out-patient clinic. Previously, diabetes education was delivered on an unstructured individual basis, with regular metabolic self-monitoring (urine and/or blood glucose testing) being taught to selected patients only. Patients were not advised to alter their insulin dosage without contacting a physician and major emphasis was placed upon a rigid dietary regimen. In Düsseldorf in 1978 and in Vienna in 1981, a structured diabetes teaching and treatment programme, modified according to Assal and Pernet [6], was instituted.

Teaching was organized as an in-patient course for 6-12 patients from Monday morning to Friday afternoon. The course included about $17 \mathrm{~h}$ of theoretical and practical group teaching, delivered by a 
Table 1. Clinical data of patients at entry into the study

\begin{tabular}{|c|c|c|c|}
\hline & $\begin{array}{l}\text { Vienna } \\
(n=50)\end{array}$ & $\begin{array}{l}\text { Düsseldorf } \\
(n=38)\end{array}$ & $p$ \\
\hline Age (years) & $26 \pm 8$ & $28 \pm 8$ & NS \\
\hline $\begin{array}{l}\text { Duration of diabetes } \\
\text { (years) }\end{array}$ & $10 \pm 6$ & $9 \pm 6$ & NS \\
\hline $\begin{array}{l}\text { Body mass index } \\
(\mathrm{kg} \text { body weight } \cdot \mathrm{m} \\
\left.\text { height }^{-2}\right)\end{array}$ & $22.2 \pm 2.6$ & $21.7 \pm 3.2$ & NS \\
\hline $\begin{array}{l}\text { Daily insulin dosage } \\
(\mathrm{U} \cdot \mathrm{kg} \text { body } \\
\left.\text { weight }^{-1} \cdot \text { day }^{-1}\right)\end{array}$ & $0.8 \pm 0.3$ & $0.7 \pm 0.2$ & NS \\
\hline \multicolumn{4}{|l|}{ Number of patients using: } \\
\hline 1 insulin injection/day & $8(16 \%)$ & $4(10 \%)$ & \\
\hline 2 insulin injections/day & $38(76 \%)$ & $33(87 \%)$ & \\
\hline 3 insulin injections/day & $4(8 \%)$ & $1(3 \%)$ & NS \\
\hline $\begin{array}{l}\text { Number of patients using } \\
\text { regular (soluble) insulin }\end{array}$ & $35(70 \%)$ & $5(13 \%)$ & $<0.001$ \\
\hline $\begin{array}{l}\text { Number of patients with } \\
\text { late diabetic } \\
\text { complications }^{\mathrm{a}}\end{array}$ & $25(50 \%)$ & $13(35 \%)$ & NS \\
\hline $\begin{array}{l}\text { Glycosylated haemoglobin } \\
\text { (excess above normal } \\
\text { range, as } \% \text { total } \\
\text { haemoglobin) }\end{array}$ & $+2.4 \pm 2.0$ & $+2.7 \pm 2.1$ & NS \\
\hline $\begin{array}{l}\text { Hospital admissions since } \\
\text { diagnosis of diabetes } \\
\text { (days per patient per } \\
\text { year) }\end{array}$ & 9 & 12 & NS \\
\hline $\begin{array}{l}\text { Patients re-examined at the } \\
\text { time of follow-up } \\
\text { evaluation }\end{array}$ & $44(88 \%)$ & $34(89 \%)$ & NS \\
\hline
\end{tabular}

${ }^{a}$ Retinopathy and/or neuropathy and/or nephropathy; NS not significant. Results expressed as mean $\pm \mathrm{SD}$

diabetes teaching nurse, dietitian, and laboratory technician under the guidance of the medical staff. The therapeutic and educational goals, as well as strategies for insulin therapy and the teaching programme were identical in Vienna and Düsseldorf. Thus the patients were to attempt (near-) normoglycaemia and handle minor metabolic derangements without contacting a doctor. They should gain a certain 'liberalisation' of life style with respect to exercise and eating schedules, and their relatives would administer glucagon in case of severe hypoglycaemia; all patients, irrespective of their educational status or intelligence, should be trained for self-management of their diabetes. Permanent improvement of metabolic control can be maintained only by daily self-monitoring of blood glucose or urine sugar and appropriate adaptation of the treatment by patients themselves. In addition, the insulin regimen must allow for immediate corrections of metabolic control. Therefore, regular (soluble) insulin has to be an essential component of insulin therapy. Thus, patients were instructed to monitor three to four times per day either urine glucose (Clinitest, Ames) or blood glucose (Haemoglucotest 20-800, Boehringer Mannheim; Dextrostix, Ames, with or without a reflectance meter), and to record the results in $\log$ books. Insulin therapy was either with Monotard MC and Actrapid MC (Novo, Copenhagen) or with Insulatard and Velosulin (Nordisk, Copenhagen). As a rule, patients injected individually adjusted combinations of these insulins in the morning and in the evening.

\section{Patients}

All conventionally treated (one or more $\mathrm{SC}$ insulin injections per day) Type 1 diabetic patients $(n=88)$, admitted to the diabetic wards of the University Hospitals of Vienna $(n=50)$ and Düsseldorf $(n=38)$ between January and June 1981, were included in the study. As a rule, these patients were referred by family physicians or transferred from other hospitals. On admission, clinical data (Table 1) were comparable between the subgroups of Vienna and Düsseldorf, the insulin regimen being the only exception. In Vienna, most patients were already treated with mixtures of regular and intermediate long-acting insulins (Table 1). All patients participated in the diabetes teaching programme. After discharge from hospital they were, in general, followed up by their family physicians, although they did have access to the diabetes clinics of the two hospitals either through visits or by telephone.

\section{Evaluation Protocol}

In April 1982, 12.6 \pm 1.7 months (mean \pm SD) after participation in the teaching programme, all 88 patients were asked at short notice to come for a follow-up examination to the out-patient clinic, bringing their log books. Twelve had to be visited at home. The follow-up evaluation included: recording of body weight, laboratory measurements, a standardized interview, completion of an intelligence test, and the assessment of various measures of compliance. The data were obtained and recorded by two independent, specially trained medical students, previously unknown to the patients.

\section{Laboratory Assessments}

Glycosylated haemoglobin: during 1981, in Vienna, the microcolumn method (Iso-Lab, [9]) was used (normal range $5.9 \%-8.7 \%$ of total haemoglobin, mean \pm 2 SD of 100 normal controls). After a period of several weeks during which both methods were used in parallel, in January 1982 the analytical procedure was changed to the microcolumn method plus initial aldimine extraction of the Schiff base [10]. As a consequence, the normal range dropped to $4.9 \%-8.1 \%$ (mean \pm $2 \mathrm{SD}$ of 50 normal controls). In Düsseldorf, the thiobarbiturate method [11] was used (normal range $4.1 \%-7.8 \%$, mean \pm 2 SD of 52 control subjects). Since the upper limit of the normal range is roughly the same for all three methods, glycosylated haemoglobin levels were expressed as the amount per cent of total haemoglobin by which they exceeded the upper limit of the normal range. For the Vienna subgroup, glycosylated haemoglobin was measured also $3.0 \pm 2.1$ and $8.2 \pm 1.1$ months (mean $\pm \mathrm{SD}$ ) after participation in the diabetes teaching programme, using the same method of determination as initially.

C-peptide: non-fasting C-peptide levels were measured by radioimmunoassay, using a commercially available kit (Behring, Marburg, FRG [12]). Patients with levels below $0.3 \mathrm{ng} / \mathrm{ml}$ were defined as Cpeptide-negative.

\section{Standardized Interview}

Incidence of severe hypoglycaemia: severe hypoglycaemia was defined as loss of consciousness treated with either glucagon injection or IV glucose.

Incidence of hospital admissions: all hospital admissions, diabetesrelated or not, were expressed as hospital days per patient per year.

Diabetes-related knowledge: diabetes-related knowledge was assessed using an illustrated questionnaire with 36 questions on general aspects of diabetes, self-monitoring, rules for changing insulin dose, treatment and prevention of hypoglycaemia, and diet. The total internal reliability $\left(r_{t t}\right)$ of the questionnaire was 0.8 assessed according to Lienert [13].

\section{Assessment of Compliance}

Rates of compliance with the following items of the diabetes teaching and treatment programme were evaluated: (1) patients were asked to prove that they were carrying emergency carbohydrates for treatment of hypoglycaemia; (2) they were asked to present their diabetes $\log$ 
Table 2. Treatment, metabolic control and hospital admissions in 78 patients before and 12 months after the diabetes teaching and treatment programme

\begin{tabular}{|c|c|c|c|}
\hline & $\begin{array}{l}\text { Before the } \\
\text { programme }\end{array}$ & $\begin{array}{l}\text { After the } \\
\text { programme }\end{array}$ & $p$ \\
\hline $\begin{array}{l}\text { Body mass index } \\
(\mathrm{kg} \text { body weight } \cdot \mathrm{m} \\
\left.\text { height }^{-2}\right)\end{array}$ & $22.0 \pm 2.9$ & $22.5 \pm 2.6$ & NS \\
\hline $\begin{array}{l}\text { Daily insulin dosage }(\mathrm{U} \cdot \mathrm{kg} \\
\text { body weight } \\
\left.-1 \cdot \mathrm{day}^{-1}\right)\end{array}$ & $0.8 \pm 0.3$ & $0.8 \pm 0.3$ & NS \\
\hline \multicolumn{4}{|l|}{ Number of patients using: } \\
\hline 1 insulin injection/day & $10(13 \%)$ & $4(5 \%)$ & NS \\
\hline 2 insulin injections/day & $63(81 \%)$ & $67(86 \%)$ & \\
\hline 3 insulin injections/day & $5(6 \%)$ & $7(9 \%)$ & \\
\hline $\begin{array}{l}\text { Number of patients using } \\
\text { regular insulin }\end{array}$ & $37(47 \%)$ & $68(87 \%)$ & $<0.01$ \\
\hline $\begin{array}{l}\text { Glycosylated haemoglobin } \\
\text { (excess above normal } \\
\text { range, as \% total } \\
\text { haemoglobin) }\end{array}$ & $+2.6 \pm 2.0$ & $+1.0 \pm 1.7$ & $<0.001$ \\
\hline $\begin{array}{l}\text { Patients with at least one } \\
\text { severe hypoglycaemic } \\
\text { episode per year }(\%)\end{array}$ & 4 & 13 & NS \\
\hline $\begin{array}{l}\text { Hospital admissions (days } \\
\text { per patient per year; } \\
\text { median) }\end{array}$ & 10 & 1 & $<0.001$ \\
\hline
\end{tabular}

NS not significant. Results expressed as mean \pm SD

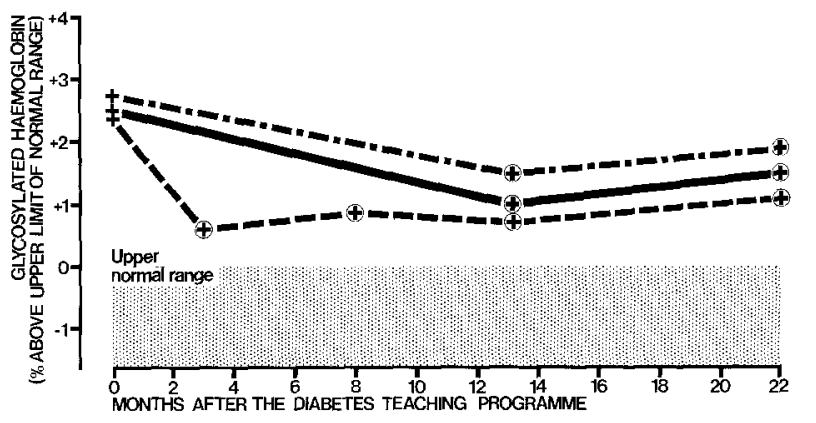

Fig. 1. Effect of the diabetes teaching and treatment programme on glycosylated haemoglobin levels over a period of 22 months. +-+ all patients $(n=78) ;+\cdots--+$ Vienna subgroup $(n=44) ;+\cdots \cdot .+$ Düsseldorf subgroup $(n=34)$. Circled values are significantly different from the respective initial values

books; (3) frequencies of metabolic self-monitoring; (4) frequencies of insulin dose changes were assessed by analyzing the log book entries covering the last 4 weeks before the follow-up examination, as well as the period from 8 to 4 weeks before the study (patients were also asked about self-monitoring not recorded in their log books); and (5) performance of glucagon administration by relatives in case of severe hypoglycaemia was evaluated by standardized interview. In Vienna, compliance rates (1) to (5) were evaluated before as well as after patients participated in the diabetes teaching programme.

\section{Intelligence Test}

Intelligence quotients were assessed, using the modified HAWIE verbal test [14].

\section{Visits to the Out-Patient Clinics}

Numbers of visits to the out-patient units of the two hospitals were assessed from out-patient unit records.
The insulin regimen was recorded and calculated as the mean daily dosage during the last 4 weeks, expressed as $U \cdot \mathrm{kg}_{\text {body weight }}{ }^{-1}$. day $^{-1}$.

\section{2-Month Follow-up Assessment}

$21.7 \pm 2.0$ months after the diabetes teaching and treatment programme, metabolic control was re-evaluated by assessing glycosylated haemoglobin levels and the incidence of severe hypoglycaemia.

\section{Statistical Analysis}

Data were analyzed using the 'Statistical Package of Social Sciences'. All data are expressed as mean $\pm S D$, unless otherwise indicated. Statistical tests used for analyses were Student's t-test for paired and unpaired data, Chi square, Kruskal-Wallis 1-way analysis of variance, Pearson's test, Wilcoxon test, Mann-Whitney-U test, McNemar test. A $p$ value below 0.05 was considered statistically significant.

\section{Results}

For 86 of the 88 patients, some follow-up information was obtained. In 78 patients a complete evaluation was performed at the time set for follow-up. Clinical data of these 78 patients are summarized in Table 2 . Both body weight and insulin dosage remained constant over the study period. In Vienna the insulin regimen had not been altered, whereas in Düsseldorf the percentage of patients using regular insulin had increased from 13 to $89 \%$ as a result of the initial therapeutic intervention. Eighty-one percent of patients had undetectable C-peptide levels. Glycosylated haemoglobin (expressed as amount percent of total haemoglobin above the upper limit of the normal range) dropped from $+2.6 \pm 2.0$ to $+1.0 \pm 1.7(p<0.001$, Fig. 1$)$. In Vienna, the follow-up values were $+2.4 \pm 2.0,+0.6 \pm 1.3,+0.9 \pm 1.7$, and $0.7 \pm 1.8(p<0.001)$ and in Düsseldorf $+2.7 \pm 1.9$ and $+1.5 \pm 1.8(p<0.001$, Fig. 1$)$.

\section{Severe Hypoglycaemia}

At the one-year follow-up, 11 of 86 patients had experienced 33 severe hypoglycaemic episodes. However, four patients experienced more than two severe hypoglycaemic attacks per year, and $76 \%$ of all episodes occurred in these four patients. All four had normal levels of glycosylated haemoglobin and had performed daily self-monitoring. As probable causes for the extraordinary incidence of severe hypoglycaemia in these four patients, we have identified treatment with excessively high insulin doses, excessive alcohol consumption, pregnancy and kidney failure.

\section{Hospital Admissions}

Before the diabetes teaching programme, the mean hospital days per patient per year of diabetes was 10 . At follow-up, 18 of 86 patients had been hospitalised during 
Table 3. Compliance rates before and after the diabetes teaching and treatment programme

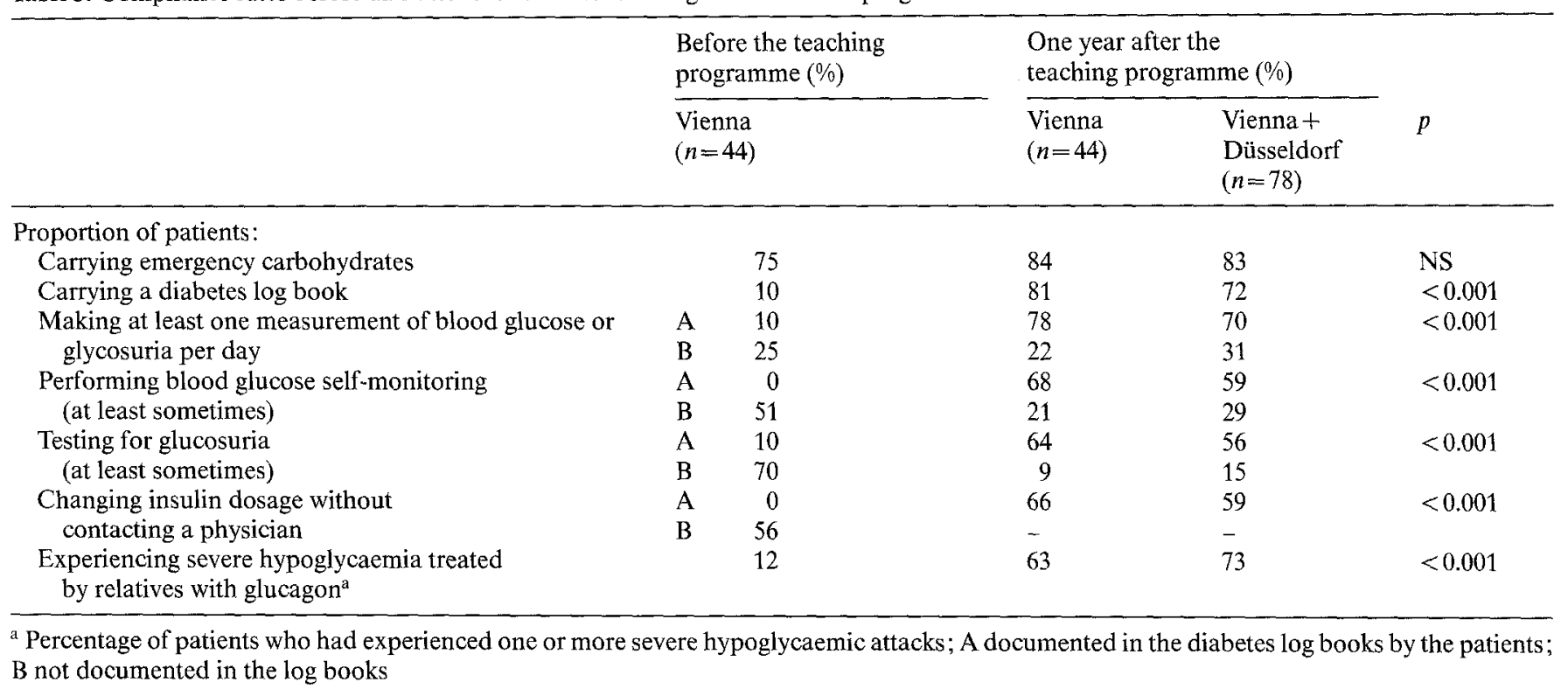

the year after the teaching programme and the median of hospital days over all patients per year was $1(p<$ 0.001 , Table 2).

\section{Diabetes-related Knowledge}

On average $75 \%$ of the questions were answered correctly. The mean knowledge score was $28 \pm 4$ (out of a maximum of 36 ). There were no significant associations between individual knowledge scores and any other variables investigated.

\section{Compliance}

Overall compliance rates improved significantly (Table 3). Fifty-six of the 78 patients had a log book with them at follow-up. Entries did not differ significantly between the 4-week period immediately before the follow-up examination and the period from 8 to 4 weeks before the study. Therefore, only recordings from the last 4 weeks before the study were analyzed in detail. Of the 56 patients able to present their log books, $38 \%$ had recorded results of blood glucose measurements only, $34 \%$ those of urine glucose only, and $28 \%$ had recorded both results from blood and urine glucose determinations. Forty-five percent of the 56 patients with $\log$ books had more than $80,30 \%$ between 60 and 80 , and $25 \%$ less than 60 results of blood or urine glucose measurements recorded during the 28 day period.

\section{Intelligence}

The mean intelligence quotient was $108 \pm 16$. There were no relationships between intelligence and any other variables investigated.

\section{Number of Visits in the Out-patient Unit}

Eighty-three percent of patients were seen at least once in the diabetic out-patient units (mean $6 \pm 3$ visits per patient per year). There were no significant relationships between the number of visits and other variables investigated.

\section{2-Month Follow-up}

At the 22-month follow-up, glycosylated haemoglobin levels in 77 patients were $+1.5 \pm 2.1 \%$ above the upper limit of normal range $(p<0.001$ compared with the value before the teaching and treatment programme, and not significantly different from the one-year follow-up value). Separate values for the Düsseldorf and Vienna subgroups are shown in Figure 1. At that time, 16 of 87 patients had experienced 44 episodes of severe hypoglycaemia during the 22 months following the diabetes teaching and treatment programme.

\section{Evaluation of Subgroups Defined According to Glycosylated Haemoglobin Levels at the Follow-up Examination}

At the one-year follow-up examination, 26 patients had glycosylated haemoglobin values within the normal range, and 22 patients had values equal to or exceeding $+2 \%$ above the normal range. Data of these two patient groups are compared in Table 4. Initial values of glycosylated haemoglobin were significantly lower in patients with normal values of glycosylated haemoglobin at follow-up. In addition, significantly more of these patients could prove that they were carrying emergency carbohydrates and their diabetes log books. 
Table 4. Evaluation of patients according to their levels of glycosylated haemoglobin at follow-up

\begin{tabular}{|c|c|c|c|}
\hline & $\begin{array}{l}\text { Glycosylated } \\
\text { levels (\%) }\end{array}$ & haemoglobin & $p$ \\
\hline & $\begin{array}{l}\text { Within } \\
\text { normal range } \\
(n=26)\end{array}$ & $\begin{array}{l}\geqslant+2 \% \text { above } \\
\text { normal range } \\
(n=22)\end{array}$ & \\
\hline Age (years) & $29 \pm 10$ & $28 \pm 10$ & NS \\
\hline $\begin{array}{l}\text { Duration of diabetes } \\
\text { (years) }\end{array}$ & $12 \pm 7$ & $11 \pm 8$ & NS \\
\hline $\begin{array}{l}\text { Daily insulin dosage }(\mathrm{U} \cdot \mathrm{kg} \\
\text { body weight } \\
\left.-1 \cdot \text { day }^{-1}\right)\end{array}$ & $0.7 \pm 0.3$ & $0.7 \pm 0.2$ & NS \\
\hline $\begin{array}{l}\text { Proportion of patients } \\
\text { using: }\end{array}$ & & & \\
\hline 1 insulin injection/day & $6 \%$ & $5 \%$ & \\
\hline 2 insulin injections/day & $82 \%$ & $90 \%$ & \\
\hline 3 insulin injections/day & $12 \%$ & $5 \%$ & NS \\
\hline $\begin{array}{l}\text { Proportion of patients } \\
\text { using regular (soluble) } \\
\text { insulin }\end{array}$ & $94 \%$ & $86 \%$ & NS \\
\hline $\begin{array}{l}\text { Proportion of } \mathrm{C} \text {-peptide } \\
\text { negative-patients }\end{array}$ & $73 \%$ & $82 \%$ & NS \\
\hline $\begin{array}{l}\text { Number of patients with at } \\
\text { least one severe hypogly- } \\
\text { caemia during the } 1 \text {-year } \\
\text { follow-up }\end{array}$ & 5 & 2 & NS \\
\hline $\begin{array}{l}\text { Initial value of glycosylat- } \\
\text { ed haemoglobin (excess } \\
\text { above normal range, as } \\
\% \text { total haemoglobin) }\end{array}$ & $+1.5 \pm 1.9$ & $+3.6 \pm 2.1$ & $<0.001$ \\
\hline Intelligence quotient & $107 \pm 16$ & $110 \pm 16$ & NS \\
\hline $\begin{array}{l}\text { Proportion of } \\
\text { patients carrying a } \\
\text { diabetes log book }\end{array}$ & $85 \%$ & $57 \%$ & $<0.03$ \\
\hline $\begin{array}{l}\text { Proportion of patients car- } \\
\text { rying emergency carbo- } \\
\text { hydrates }\end{array}$ & $100 \%$ & $76 \%$ & $<0.05$ \\
\hline $\begin{array}{l}\text { Diabetes-related knowl- } \\
\text { edge score (out of a max- } \\
\text { imum of } 36 \text { ) }\end{array}$ & $29 \pm 3$ & $29 \pm 3$ & NS \\
\hline $\begin{array}{l}\text { Frequencies of visits to the } \\
\text { out-patient unit during } \\
\text { the follow-up period } \\
\text { (visits per year) }\end{array}$ & $6 \pm 4$ & $7 \pm 5$ & NS \\
\hline
\end{tabular}

Results expressed as mean $\pm \mathrm{SD}$; NS not significant.

\section{Differences in the Evaluation Results Between Subgroups Vienna and Düsseldorf}

Separate analysis of the Vienna- and Düsseldorf-subgroup revealed that the frequency of C-peptide-negative patients was somewhat higher in Düsseldorf (91\%) than in Vienna $(73 \%)$. Values of glycosylated haemoglobin were at all times slightly lower in the Vienna group, but the reduction of glycosylated haemoglobin levels following the teaching and treatment programme was identical in both groups.

\section{The Patient Group not Completely Evaluated at the 1-Year Follow-up Examination}

Ten patients could not be included in the follow-up evaluation: one had committed suicide, two had emi- grated, and four could not be contacted, although three of the latter were seen in the out-patient clinic 6-14 weeks thereafter; at that time, glycosylated haemoglobin levels were $8.0 \%, 11.4 \%$ and $7.2 \%$. The remaining three patients refused to participate in the follow-up examination. However, information about the incidence of severe hypoglycaemia and hospital admission was obtained either through personal or telephone contact or via the family physician for all but two of the ten; no severe hypoglycaemia and only one hospital admission had occurred in these patients. In addition, there were no significant differences in clinical data at entry into the study between the 10 diabetics who did not participate at the follow-up examination as scheduled, and the 78 diabetic patients who did.

\section{Discussion}

The diabetes teaching and treatment programme evaluated in this study represents a novel approach in the care of Type 1 diabetic patients in Germany and Austria and in several other countries on the European continent. It includes encouragement for every patient, irrespective of educational or social status, to perform daily self-monitoring of blood or urine glucose levels and to adapt his insulin dosage accordingly in order to achieve both continuous (at least near-) normoglycaemia and a certain liberalization of life style, e.g. with respect to eating schedules and physical activity. Obviously, this therapeutic approach does require an intensive programme for patient education. While the educational aspects are certainly of principal importance for eventual success, the diabetes teaching and treatment programme described in this study represents an integrated therapeutic approach. Thus it is neither possible nor relevant at this stage to try to distinguish between the effects of educational and purely 'therapeutic' efforts.

The results of this bicentric study show that a structured one-week in-patient teaching and treatment programme, delivered by specifically trained paramedical staff, led to a significant improvement of glycosylated haemoglobin levels for at least 22 months, as well as a significant reduction in hospital admissions, in conventionally treated Type 1 diabetic patients.

All patients with Type 1 diabetes who were admitted to the two hospitals during a certain period participated in the teaching and treatment programme, and all were included in the study protocol. In general, these patients were referred by family physicians or transferred from other hospitals; thus they were new to the staff of the diabetes wards of our hospitals.

In $89 \%$ of these patients a complete, and in $9 \%$ a partial follow-up evaluation was performed, whereas only $2 \%$ were completely lost to follow-up. In addition, the information collected on the $9 \%$ of the cohort who did not participate in the complete evaluation proce- 
dure indicates that they did not differ from the others with respect to the quality of diabetes care that had been achieved.

By collecting information on the quality of diabetes care (incidence of hospital admissions for a mean diabetes duration of 10 years, values of glycosylated haemoglobin, diabetes-related behaviour), pre-intervention control data were obtained for each patient. Since the patients were referred to our hospitals for stabilization of metabolic control, it was not feasible to divide them into two groups within one institution; that is, it was impossible to withhold a separate cohort of patients ('controls') from the intensive diabetes teaching and treatment programme as instituted in our diabetes wards [15, 16].

Diabetic patients with normal values of glycosylated haemoglobin on follow-up examination did not differ significantly from those who had values more than $+2 \%$ above the upper limit of the normal range with regard to duration of diabetes, insulin therapy, intelligence quotient, diabetes-related knowledge or frequency of visits to the out-patient clinics. The patients with normal glycosylated haemoglobin levels had, however, significantly lower values of glycosylated haemoglobin at the beginning of the study and were significantly more compliant, at least to some goals of the educational programme.

Recently, Worth et al. published an investigation assessing the long-term effects of a structured teaching and treatment programme on glycosylated haemoglobin levels in selected adult insulin-dependent patients with long-standing diabetes [8]. These authors failed to show any improvement in glycosylated haemoglobin levels persisting beyond 6 months after the end of the teaching programme. Their failure might have been partly due to the fact that the method of diabetes education used was quite different from that used here, and also to the rigid rules for metabolic self-monitoring which had been imposed on their patients. The results of the present study underline the advantage of allowing the 'educated' patient to choose his/her individual schedules and methods of self-monitoring. Thus, about one-third of the patients in this study preferred measuring blood glucose exclusively, another third tested their urine only, and the remainder chose to alternate between the two methods on a more or less systematic basis.

Excess hospital admissions of diabetic patients with respect to age-matched non-diabetic populations have been reported in a number of investigations $[3,17]$. Accordingly, we have found a mean of 10 hospital days per year over a mean period of 10 years before the patients had been referred to us. Following the diabetes teaching and treatment programme, the admission rate fell to a median of 1 day per patient during the year of the follow-up period. Due to the organisation of our health care systems, it was usually impossible to trace the exact reasons for these hospital admissions because, in general, they were to institutions other than our hospitals.

The decrease of hospital days documented in this study represents a substantial reduction in health care costs, even when the increased use of self-monitoring materials by the patients is taken into account.

Improvement of metabolic control might be associated with an increasing incidence of severe hypoglycaemia. In this study, $13 \%$ (12-month follow-up) or $11 \%$ (22-month follow-up) respectively of the patients had experienced at least one severe hypoglycaemic episode per year, compared with $4 \%$ of patients per year before they entered the study. (The latter figure is, however, almost certainly an underestimate, as it was extracted from case histories recollected by the patients over a mean of approximately 10 years.) Other investigators have reported figures as high as $26 \%$ and $31 \%$ of adult insulin-treated patients experiencing at least one severe hypoglycaemic attack per year - but no adequate assessment of metabolic control was available for the patients in these studies $[18,19]$. It was an unexpected finding in the present investigation that at the one year follow-up $4 \%$ of the patients had experienced $74 \%$ of all severe hypoglycaemias; all had normal levels of glycosylated haemoglobin and had performed regular metabolic self-monitoring. Following the reduction of the excessive insulin dosages found in two patients, no further severe hypoglycaemia occurred during the second year of follow-up, while levels of glycosylated haemoglobin remained within the normal range. Based on information collected from 402 Type 1 diabetic patients over a follow-up period of 18 months after our diabetes teaching and treatment programme, we have found that $10 \%$ of patients had at least one severe hypoglycaemic attack per year [20] - a result which compares most favourably with the surprisingly limited literature in this area of concern.

This study demonstrates the efficiency of a diabetes teaching and treatment programme in improving diabetes care in two different centres. Diabetes education, organized as an integral part of the therapeutic programme and intended to make patients more independent in the day-to-day management of their disease, was associated with a significant improvement of metabolic control and a substantial reduction of projected health care costs over a period of approximately 2 years in a large number of unselected Type 1 diabetic patients. Except for some cases of apparent mismanagement during the follow-up period, no excess of severe hypoglycaemia occurred. In addition, the study substantiates the feasibility of using this diabetes teaching and treatment programme in other hospitals.

Acknowledgements. We gratefully acknowledge the skilful and dedicated cooperation of Ms. K. Heininger-Wasser (Registered-Nurse), Chr. Broermann and A. Nakrour (laboratory technicians), G. Gösseringer, and M. Binder (Registered Dietitians) 


\section{References}

1. WHO Expert Committee on Diabetes Mellitus (1980) Second report. World Health Organization Technical Report Series No 646, Geneva

2. Graber AL, Christman BG, Alogna MT, Davidson JK (1977) Evaluation of diabetes patient-education programs. Diabetes 26: 61-64

3. Miller LV, Goldstein J (1972) More efficient care of diabetic patients in a county-hospital setting. N EngI J Med 286: 1388-1391

4. Moffitt P, Fowler J, Eather G (1979) Bed occupancy by diabetic patients. Med J Aust 1: 244-245

5. Davidson JK, Alogna M, Goldsmith M, Borden J (1981) Assessment of programme effectiveness at Grady Memorial Hospital Atlanta. In: Steiner G, Lawrence PA (eds) Educating diabetic patients. Springer, New York, pp 329-348

6. Assal JP, Pernet A (1982) Education as a part of therapy. In: Krall LP (ed) World book of diabetes in practice 1982, Excerpta Medica, Amsterdam, pp 73-78

7. Etzwiler DD, Robb JR (1972) Evaluation of programmed education among juvenile diabetics and their families. Diabetes 21 : 967-971

8. Worth R, Home PD, Johnston DG, Anderson J, Ashworth L, Burrin JM, Appleton D, Binder C, Alberti KGMM (1982) Intensive attention improves glycaemic control in insulin-dependent diabetes without further advantage from home blood glucose monitoring: results of a controlled trial. $\mathrm{Br}$ Med J 285: 1233-1240

9. Abraham EC, Huff TA, Cope ND, Wilseon JB, Bransome EB, Huisman THS (1978) Determination of the glycosylated haemoglobin $\left(\mathrm{HbA}_{1}\right)$ with a new micro-column procedure. Diabetes 27 : 931-937

10. Reinauer H (1983) Glykosylierte Hämoglobine. Chemische Grundlagen der Bildung und Beseitigung der Aldiminform. Z Lab Med (in press)

11. Fischer RW, DeJong C, Voigt E, Berger W, Winterhalter $\mathrm{KH}$ (1980) The colorimetric determination of $\mathrm{HbA}_{1 \mathrm{c}}$ in normal and diabetic subjects. Clin Lab Haematol 2: 129-138
12. Kuzuya H, Blix PM, Horwitz DL, Steiner DF, Rubenstein AH (1977) Determination of free and total insulin and C-peptide in insulin-treated diabetics. Diabetes 26: 22-29

13. Lienert GA (1969) Testaufbau und Testanalyse. Beltz, Weinheim, FRG

14. Lehrl S, Daun H, Schmidt R (1971) Eine Abwandlung des HAWIE-Wortschatztests als Kurztest zur Messung der Intelligenz Erwachsener (1971) Arch Psychiat Nervenkr 214: 353-364

15. Mühlhauser I, Schernthaner G (1982) Diabetikerschulung mit dem Ziel der Selbsttherapie - Grundlage jeder erfolgreichen Diabetesbehandlung. Oesterr Ärzte Ztg 37:263-267

16. Berger M, Jörgens V, Mühlhauser I, Zimmermann H (1983) Die Bedeutung der Diabetikerschulung in der Therapie des Typ-I Diabetes. Dtsch Med Wochenschr 11:424-430

17. Green, A, Solander F (1983) Epidemiological studies of diabetes mellitus in Denmark: 6. Use of hospital services by insulin-treated diabetic patients. Diabetologia (in press)

18. Goldgewicht C, Slama G, Papoz L, Tchobroutsky G (1983) Hypoglycaemic reactions in 172 Type 1 (insulin-dependent) diabetic patients. Diabetologia 24: 95-99

19. Basdevant A, Costagliola D, Lanöe JL, Goldgewicht C, Triomphe A, Metz F, Denys H, Eschwege E, Fardeau M, Tchobroutsky G (1982) The risk of diabetic control: a comparison of hospital versus general practice supervision. Diabetologia 22: 309-314

20. Koch J, Mühlhauser I, Jörgens V, Kunz A, Graninger W, Schernthaner $G$, Berger $M$ (1983) Incidence and management of severe hypoglycaemia in 402 type-I diabetic patients: follow-up 1.5 years after an intensified teaching and treatment programme. Diabetologia 25: 171 (Abstract)

Received: 8 May 1983

and in revised form: 6 October 1983

Dr. I. Mühlhauser

Medizinische Klinik E der Universität Düsseldorf

Moorenstraße 5

D-4000 Düsseldorf, FRG 